\title{
THE HERITAGE OF THE ILLYRIAN PROVINCES AS AN ELEMENT OF PRO-YUGOSLAV PROPAGANDA DURING THE REIGN OF KING ALEXANDER I OF YUGOSLAVIA
}

PAWEL MICHALAK

INDEPENDENT SCHOLAR, POZNAŃ

\begin{abstract}
The biggest threat to the stability of the Kingdom of Serbs, Croats and Slovenes, which was created after the First World War, was the social distinctions between its citizens, who had been raised in completely different countries, and even different civilizations. The people's mentality and their various historical experiences were the consequence of living for hundreds of years in separate cultures. King Alexander Karađorđević was aware of that, and based his domestic politics on the idea of an integral "Yugoslavism," which meant the propagation of the ideal of a unified Yugoslavia in all aspects of social life. The main aim of the monarch was consolidating his entire society around the Yugoslav idea, uniting all the country's citizens into one nation and creating a new kind of man or woman - homo yugoslavicus. To achieve these goals, Karađorđevićs state propaganda drew upon events and ideas from the past history of each "tribe" of the "three-name nation." In particular, the heritage of the Illyrian Provinces was used in that way. This article analyzes how the heritage of the Illyrian Provinces was used in public discourse of interwar Yugoslavia as one of the elements cementing the Yugoslav idea in the minds of the people. It focuses primarily on school curricula and the activities of influential scholars.
\end{abstract}

Keywords: Yugoslavia; Yugoslavism; Illyrian Provinces; propaganda; school curricula DOI: $10.14712 / 23363231.2020 .3$

This article is based on research supported by a grant from National Science Centre of Poland (2014/13/D/HS3/03701).

Dr Paweł Michalak is a graduate of the Faculty of History of Adam Mickiewicz University, Poznań, Poland. Mr. Michalak is a member of the Commission of the Balkan Studies of the Polish Academy of Sciences and the Polish Commission of Balkan Culture and History (AIESEE).

E-mail: p.michalak87@yahoo.com. 


\section{Introduction}

After the First World War, the Kingdom of the Serbs, Croats and Slovenes (hereinafter referred to as the Kingdom of SHS, from the Serbo-Croatian Kraljevina Srba, Hrvata i Slovenaca, which became known as the Kingdom of Yugoslavia after October 1929) was created in December 1918. The Kingdom was composed of regions which not long before had functioned in six different customs zones and with five separate currencies, four railways, and three banking systems. However, economic differences were not the biggest threat to the stability of the young Yugoslav state. Social and mental distinctions were a much more complicated problem, resulting from diverse religious confessions and historical experiences that were the consequence of hundreds of years lived in completely different countries, and even different civilizations. The distinctions contributed to stereotypes which did not help to create a common Yugoslav national identity. The constitutional structure was quite centralized, as adopted by the authorities in Belgrade (especially King Alexander Karađorđević and Nikola Pašić, the leader of the biggest Serbian political party, the National Radical Party, who was several times the prime minister of both the Kingdom of Serbia and the Kingdom of SHS). Therefore, the creation among the people of a coherent Yugoslav identity - homo yugoslavicus - was the sine qua non for the survival of the new state.

From the very beginning of Yugoslavia's existence, its central authorities appealed to the Yugoslav idea, stressing at every step that Serbs, Croats, and Slovenians living in the state were actually "three tribes of one nation," - a nation with three names (troimeni narod). ${ }^{1}$ However, their efforts did not have the results they expected for several reasons. Firstly, the Yugoslav idea was mainly that of the elites, while the society of inter-war Yugoslavia was massively a peasant society. According to the censuses of 1921 and 1931, 78.9\% and $76.6 \%$ of the population, respectively, worked in economic sectors such as agriculture, forestry and fishing. ${ }^{2}$ At that time, $44.6 \%$ of the society was illiterate. ${ }^{3}$ Considering that in the 1931 census $76.4 \%$ of the Yugoslavian population declared a willingness to spend their whole life in the place where they were born, ${ }^{4}$ it is clear how limited

1 The Muslims of Bosnia, who today identify themselves as Bošniaks, Macedonians, and Montenegrins were not considered to be a separate nation in inter-war Yugoslavia.

2 Ljubodrag Dimić, Kulturna politika Kraljevine Jugoslavije 1918-1941, Vol. I (Beograd: Stubovi kulture, 1996), 35.

3 Ibid., 192.

4 Ibid., 55-56. 
the possibilities were for opening up, exchanging ideas, and breaking down the stereotypes held by a large part of society.

Moreover, after the Communist Party of Yugoslavia was banned in August $1921,{ }^{5}$ and until the Yugoslav National Party was formed in $1932,{ }^{6}$ every major political party was regional, not nationwide. The most important parties did not represent the interests of a particular social class or interest group, but rather one of the "Yugoslav tribes." Thus the National Radical Party was the Serbian party, the Croatian Peasant Party was Croatian, the Slovenian People's Party was Slovenian, and the Yugoslav Muslim Organization represented primarily Bosnian Muslims. This state of affairs destabilized the entire parliamentary system. ${ }^{7}$ Instead of uniting the "three tribes of one nation," the regional character of the political parties added fuel to the fire of tribal conflict, paralyzing and all but destroying the democratic mechanisms of parliamentarism.

Taking these factors into account, forming a common Yugoslav identity from the bottom up seemed impossible. Therefore, as he assumed the role of dictator in January 6, 1929, King Alexander announced that "between myself and the nation there are no longer any intermediaries." 8 Under the slogan "one king, one state, one nation," he introduced the idea of "integral Yugoslavism," with the aim of systematically shaping the consciousness of homo yugoslavicus. The entire state apparatus was harnessed to achieving his goal. Schools, choirs, and "Sokol" organizations, as well as governmental institutions, were all incorporated into King Alexander's propaganda machine. The symbolic manifestation of the King's political program was the official change of the name of the state to the Kingdom of Yugoslavia and its reorganization into 33 oblasti (counties) and nine new banovinas (provinces). It is worth mentioning that the borders of the banovinas were deliberately laid out so as to blur the ethnic divisions in the country.

It was obvious that this kind of national identity imposed from above could not root itself in Yugoslav society without the dedicated support of

5 Ivo Banac, The National Question in Yugoslavia: Origins, History, Politics (Ithaca, NY: Cornell University Press, 1984), 329; Branislav Gligorijević, "Parlamentarni sistem u Kraljevini SHS (19191929)," in Politički život Jugoslavije 1914-1945, ed. Aleksandar Acković (Beograd: Radio-Beograd, 1973), 370-371.

6 Todor Stojkov, “Unutrašnja politika vladajućih krugova u Jugoslaviji (1929-1939)," in Politički život Jugoslavije 1914-1945, ed. Aleksandar Acković (Beograd: Radio-Beograd, 1973), 395-396.

7 Mirosław Dymarski, "Społeczno-ekonomiczne i polityczne warunki kształtowania się partii politycznych na Bałkanach do lat trzydziestych XX wieku. Wprowadzenie do problemu," in Studia z nauk społecznych i humanistycznych, ed. Jerzy Juchnowski and Marian S. Wolański (Wrocław: Wydawnictwo Uniwersytetu Wrocławskiego, 2008), 75.

8 "Mome dragom narodu. Svim Srbima, Hrvatima i Slovencima," Politika, January 6, 1929. 
state-sponsored propaganda, and above all of the educational system, which undeniably did the most to create and influence this new identity. And in the educational system the most important tool - the chisel with which the new Yugoslav man would be carved out - was history.

State propaganda drew on events and ideas in the past of each tribe of the "three-name nation." The authorities tried to combine and link those events with a pro-Yugoslav policy and use them to justify the political aims of the state. The heritage of Illyria was used in that way, and the state propaganda celebrated the ancient Illyrians, the Illyrian Provinces, and an Illyrian movement. All these concepts were presented as the prologue to the Yugoslav idea. Using the Illyrian legacy to strengthen Yugoslav propaganda was important, because it allowed the state to meld the history of the Slovenes and Croats into the common Yugoslav narrative. That was needed because some of the representatives of those two nations suspected King Alexander of promoting a "Greater Serbia" under the disguise of the Yugoslav idea. By emphasizing a link between the Illyrian heritage and the Yugoslav idea, the authorities tried to avoid that suspicion.

It is worth noting that the government's activities in this regard were carried out from the very foundation of the Kingdom of SHS, but after the King assumed the dictatorship in 1929 and vigorously began to impose the Yugoslav idea from the top down in the hope of uniting the nation, they definitely gained strength.

The main purpose of this article is to show how the memory and heritage of the Illyrian Provinces were used by Yugoslav government propaganda and linked to the Yugoslav idea. Employing the methodology of the historical sciences, and based on historical sources and the existing literature on the subject, the author identified the two most important channels for mediating the state's propaganda. The first was the schools, which, with the help of textbooks and the assumptions of the curriculum, became the key propaganda tool of the authorities. The second channel was the academic activity of Yugoslav scholars, who actively promoted the Illyrian heritage in their scientific works.

The use of the educational system and the scientific elite to propagate the idea of Yugoslavism has already been the subject of research. ${ }^{9}$ However, analyzing the heritage of the Illyrian Provinces, which was important primarily for the Slovenians - the smallest tribe of the "three-name nation" - has not so far been a main goal of those investigations. For that reason, the investment into this

9 See Charles Jelavich, South Slav Nationalisms - Textbooks and Yugoslav Union before 1914, (Columbus, OH: Ohio State University Press, 1990); Ljubinka Trgovčević, Naučnici Srbije i stvaranje Jugoslavije (Beograd: Naučna knjiga, 1986); Pieter Troch, Nationalism and Yugoslavia. Education, Yugoslavism and the Balkans before World War II (London - New York: I. B. Tauris, 2015). 
research is justified and will be very useful for further research into the creation of homo yugoslavicus in interwar Yugoslavia and how selected chapters from the history of each constituent Yugoslav nation were fused into the propaganda for the Yugoslav idea.

This article is divided into three main parts: a historical introduction, in which the author deals with the memory of the Illyrian Provinces in interwar Yugoslavia; a second part, in which he presents how the memory of the Illyrian Provinces was propagated in school textbooks; and a third part, which examines the involvement of the intellectual elites, professors, and university employees in strengthening the narrative line of a continuous Yugoslav idea that goes back to the eighteenth and nineteenth centuries.

\section{The Memory of the Illyrian Provinces}

The Illyrian Provinces were created as a result of the Peace of Schönbrunn (October 14, 1809) and existed until the outbreak of the next war between France and Austria in 1813. Under the treaty, the French acquired control over the regions of Istria, Carinthia, Carniola, Gorizia, Gradisca, and an area of what is today Croatia south of the Sava River, including the areas of Vojna Krajina and Trieste. All these areas were added to Dalmatia, Dubrovnik and Kotor, over which the French had gained control in $1806 .{ }^{10}$ The newly created provinces were actually annexed to France as departments. This French bridgehead on the opposite side of the Adriatic from Italy was primarily acquired to check the British fleet and deny the Austrian Empire access to the Adriatic. It also made possible direct commercial relations with the Balkans, especially Ottoman Turkey. ${ }^{11}$

Although French rule over the Adriatic coast was a short episode in the history of the Balkan Peninsula, which cannot be compared in duration with the Venetian and Habsburg reigns over the area, ${ }^{12}$ it is difficult to find another historical period that has left behind so many indelible marks as Napoleonic rule over the Illyrian Provinces. ${ }^{13}$ It is impossible to deny the influence that the French had on the consciousness of the South Slavs in those areas. Napoleon, by naming

10 Stjepan Ćosić, “Dubrovnik under French rule (1810-1814)," Dubrovnik Annals, No. 4 (2000): 103, https://hrcak.srce.hr/8325.

11 Ibid.

12 Wojciech Sajkowski, “The Peoples Inhabiting the Illyrian Provinces Known under the Name of Morlachs - Definition of the Ethnonym in the Light of the French Literature," Res Historica, No. 41 (2016): 112, doi: 10.17951/rh.2016.41.1.111.

${ }^{13}$ George J. Prpić, “French Rule in Croatia: 1806-1813," Balkan Studies 5, No. 2 (1964): 221. 
the Provinces after the ancient Illyrians and introducing Slavic languages into their schools, unwittingly accelerated the national revival of the Slovenes and above all of the Croats. It was the Croats who in the 1830s created the Illyrian movement, headed by Ljudevit Gaj, with an eye to their Illyrian heritage. ${ }^{14}$ In the future, the Illyrian idea would plant the seed of the Yugoslav idea in the minds of Serbs and Croats. It is considered to be one stage in the evolution of the Yugoslav movement. ${ }^{15}$

As already mentioned, two of the most difficult problems in the creation of a "Yugoslav" society were overcoming historical, social and economic differences and finding factors that could unite the country and build a sense of a Yugoslav historical continuum. One of the elements used for this purpose by state propaganda was history. Many attempts were made to pick out the historic threads that were important for each nation, so as to weave them into the fabric of common experience that was "Yugoslavism." The history of the Illyrian Provinces, which featured prominently in the school textbooks of interwar Yugoslavia as the foundation of the Yugoslav idea, was one such thread.

At the end of the nineteenth century and in the first half of the twentieth century, especially in the interwar period, the memory of the Illyrian Provinces was mythologized in the collective consciousness of Yugoslavs, particularly that of the South Slav inhabitants of Austria-Hungary. Admittedly, during the existence of the Illyrian Provinces a significant number of Slovenes and Croats, most of whom were peasants, were not very enthusiastic about French rule. First of all, the French were newcomers with whom it was impossible to communicate. Secondly, the French post-revolutionary attitude to the Catholic Church, which was embodied in the Napoleonic Code, separated church and state and permitted civil weddings, inter alia. For the most part, that was unacceptable to the predominantly Catholic, conservative society of the region. ${ }^{16}$

The turn of the nineteenth and twentieth centuries was marked by the rise of nationalism, national consciousness, and increasing tensions in the European

${ }^{14}$ On the Illyrian movement, see Elinor Murray Despalatović, Ljudevit Gaj and the Illyrian Movement (New York: Columbia University Press, 1975). See also Joanna Rapacka, Godzina Herdera. O Serbach, Chorwatach i idei jugostowiańskiej (Warszawa: Energeia, 1995).

15 Carole Rogel, The Slovenes and Yugoslavism 1890-1914 (New York: Columbia University Press, 1977), 8-9.

16 Peter Vodopivec, "Illyrian Provinces from a Slovene Perspective: Myth and Reality," in Napoleon's Empire. European Politics in Global Perspective, ed. Ute Planert (New York: Palgrave Macmillan, 2016), 256. 
multinational empires. ${ }^{17}$ South Slav intellectuals began to look for a foundation for their beliefs in the history of their various nations, on which they could build a single "house for the Yugoslav idea." One cornerstone of that foundation was the memory of the Illyrian Provinces. That history, and the history of French contacts with the Yugoslavs, was met with considerable interest when it was taught in the school curriculum of the interwar period..$^{18}$ One of the main goals of cultivating the memory of the Provinces was strengthening the narrative of a spiritual community and a destiny shared by all Yugoslavs. It was a memory that identified the Yugoslav idea as the crowning achievement of a centuries-old effort to bring it into reality.

\section{The Illyrian Provinces and the Pro-Yugoslav Narrative in the Interwar Yugoslav School Curriculum}

In the early twentieth century, the Illyrian Provinces came to be regarded by some of the Southern Slavs in Austria-Hungary as the beginning of a Yugoslav identity. For Serbs from the Principality of Serbia, the history of the Provinces was an element in the Serbian national revival, but it was assigned marginal importance in the transition to unification of the Southern Slavs. This difference can be seen in the school textbooks used in the Kingdom of Serbia in the early twentieth century, where the history of the Illyrian Provinces was little mentioned. The main reference point in Serbian textbooks was the First Serbian Uprising (1804-1813), headed by Đorđe Petrović (Karađorđe). In the textbooks that dealt with Serbian history after 1450, the story of the nine years of the First Serbian Uprising comprised $20-50 \%$ of their content, depending on the edition. The history of the Middle Ages was merely considered a prelude to the cornerstone of modern Serbian statehood, which was the First Serbian Uprising. ${ }^{19}$

There are several events in the nineteenth century history of the Balkans that were regarded as precursors of South Slav unity in the textbooks from the beginning of the twentieth century. These include the Illyrian movement of Ljudevit Gaj and the pro-Slav activities of many others, including Franjo Rački and Josip Juraj Strossmayer. ${ }^{20}$ However, it must be recognized that the most attention was

17 This tension is reflected in the period of Károly Khuen-Héderváry's rule as the Ban of Croatia (1883-1903), which was strongly marked by Magyarization.

18 Vodopivec, "Illyrian Provinces from a Slovene Perspective," 252.

19 Jelavich, South Slav Nationalisms, 190.

20 See, for example, Mirjana Gross, "Croatian National-Integrational Ideologies from the End of Illyrism to the Creation of Yugoslavia," Austrian History Yearbook 15-16 (1979-1980), 3-43, doi: 
devoted to the creation of the Illyrian Provinces by Napoleon. The provinces were discussed in the context of the liberation of the Serbs from the Habsburg yoke. But the "Illyrian Kingdom," as the provinces were called, mainly meant the areas of Dalmatia and Croatia. It ignored the other lands that made up its administrative structure. The authors of the Serbian textbooks seemed to forget about the fact that among the 1.56 million inhabitants of the Illyrian Provinces in the 1810s, the overwhelming majority were Slovenes and Croats, followed by Italians and Germans. The Serbs were only the fifth largest nation in the provinces. ${ }^{21}$ Taking all this into account, the history curriculum in interwar Yugoslavia required changes and systemic revisions aimed at conveying a unified message regarding the Illyrian Provinces and a coherent narrative about the unifying nature of its administrative structure.

Teachers and schools very quickly became tools for building a common national identity, basically from the very beginning of the existence of the Kingdom of SHS. For the first ten years of its existence, the Kingdom was the common home of the three-name nation of Serbs, Croats and Slovenians. After the introduction of dictatorship and the doctrine of integral Yugoslavism, the cultivation of a common Yugoslav identity, expressed in the taxonomy of homo yugoslavicus, was a major task.

On March 16, 1919, the future King Alexander Karađorđević, already the regent of the Kingdom, gave an interview in which he discussed the historical mission of Yugoslavia's teachers. The ruler praised the teachers as people who, despite hundreds of years of enslavement, had always cared about developing a model of teaching in which the brotherhood and unity of the Southern Slavs was always foremost, but the individual characteristics of each tribe of the threename nation were not diminished. ${ }^{22}$

In order to control and unite the teachers coming from different parts of the Kingdom (Croatia, Slovenia, Serbia, Bosnia, Montenegro, etc.), the Yugoslav Teachers Association was established under the tutelage of the State in July 1920, during a teachers' congress in Belgrade. ${ }^{23}$ Combining different groups and associations into one body controlled by the ruling elite was a trend in almost every area of life in interwar Yugoslavia. For example, the Yugoslav Journalists'

10.1017/S006723780001256X.

${ }^{21}$ Jelavich, South Slav Nationalisms, 191.

22 Ljubodrag Dimić, Kulturna politika Kraljevine Jugoslavije 1918-1941, Vol. II (Beograd: Stubovi kulture, 1997), 248-249.

${ }^{23}$ Ibid., 249; Ljubodrag Petrović, "Jugoslovenski učitelji između ideološke i društvene odgovornosti. Represija nad profesijom između dva svetska rata," Tokovi istorije, No. 1-2 (2005): 39. 
Association (formed during a congress of journalists in Sarajevo on March $26-31,1921),{ }^{24}$ the Yugoslav Sokol Association, ${ }^{25}$ and the Yugoslav Singers' Society (formed on April 6, 1924 during a congress in Ljubljana) ${ }^{26}$ followed exactly the same path.

The members of the newly formed Yugoslav Teachers Association largely supported the idea of shaping a common national identity through the teaching of history. They believed that the Serbs, Croats and Slovenians were essentially one nation, with the same origin and the same soul. ${ }^{27}$

Arbitrary guidelines and educational goals excluded teachers who refused to abandon their national identity (Serbian, Croatian or Slovenian) in favor of a Yugoslav identity. This approach only intensified over the years. It reached its apogee in 1929-1934, during the so-called integralist governments that took power when dictatorship was imposed by King Alexander. At that time, the main purpose of schools and teachers, and the main idea guiding public education, was the cultivation of homo yugoslavicus. Educating a literate citizen who could read was only secondary. ${ }^{28}$ The educational system and its curricula were based on promoting the unity of the three-name nation and glorifying the Karađorđević dynasty, which occupied one of the most important places in the national narrative. ${ }^{29}$ There was no place for teachers who did not support the Yugoslav idea. Schools were required to promote a homogeneous Yugoslav culture and a common sense of national unity. ${ }^{30}$ The teaching of the history of the Illyrian Provinces was also bent to the task of supporting the Yugoslav idea.

${ }^{24}$ Mihailo Bjelica, "Novinarske organizacije i pitanje slobode štampe u predratnoj Jugoslaviji," Novinarstvo, No. 3-4 (1988): 32; Mihailo Bjelica, 200 godina jugoslovenske štampe. Pregled istorije novinarstva (Beograd: Jugoslovenski institut za novinarstvo / Književno-izdavačka zadruga "Sloboda," 1968), 136-138.

25 On January 26, 1919, representatives of the Slovenian, Croatian and Serbian Sokol associations met in Zagreb, where they decided to establish the Sokol Union of Serbs, Croats and Slovenians. During the nationwide Sokol convention that took place on August 30, 1920 in Maribor, the name was changed to the Yugoslav Sokol Association. See Pieter Troch, "Education and Yugoslav Nationhood in Interwar Yugoslavia. Possibilities, limitations and interactions with other national ideas" (Doctoral Dissertation, Ghent University, 2012), 581-582, https://biblio.ugent.be/publication /4267482/file/4336097.pdf. See also Nikola Žutić, Sokoli. Ideologija u fizičkoj kulturi Kraljevine Jugoslavije 1929-1941 (Beograd: Angrotrade, 1991), 10.

${ }^{26}$ Ljubodrag Dimić, Kulturna politika Kraljevine Jugoslavije 1918-1941, Vol. III (Beograd: Stubovi kulture, 1997), 312; and Biljana Milanović, "Odnos sfere države prema pevačkim udruženjima u Srbiji i Kraljevini Jugoslaviji,” Muzikologija 11 (2011): 219-234.

${ }^{27}$ Dimić, Kulturna politika Kraljevine Jugoslavije, Vol. II, 249; Petrović, "Jugoslovenski učitelji," 40.

${ }^{28}$ Petrović, "Jugoslovenski učitelji," 42.

${ }^{29}$ Ibid.

${ }^{30}$ Ljubodrag Dimić, Nikola Žutić, and Blagoje Isailović, Zapisnici sa sednica Ministarskog Saveta Kraljevine Jugoslavije 1929-1931, ed. Ljubodrag Dimić, Nikola Žutić and Blagoje Isailović (Beo- 
At the beginning of the 1930s, almost half of Yugoslavs were illiterate, but some parts of the country were more literate than others. The Drava Banovina (with its center in Ljubljana) was the most highly developed in this regard. The illiteracy rate there was only about 5.6\%, while in Vrbas Banovina (centered on Banja Luka) and Vardar Banovina (Skopje) it was $72.6 \%$ and $70.9 \%$, respectively. ${ }^{31}$ In order to solve this problem, the state organized special evening courses for illiterates, which were obligatory for citizens under 25 and optional for the elderly. ${ }^{32}$ The program of these classes devoted three hours a week to geography and history combined. ${ }^{33}$ The night courses were similar to the history course in the primary schools and included the most important events in the history of the Serbs, Croats and Slovenians from the beginning of the nineteenth century.

Particular emphasis was placed on a Yugoslav way to build a common state and society in the courses. The topics included in the curriculum were the First Serbian Uprising; the Illyrian Provinces; the Second Serbian Uprising; the rebirth of Slovenian national consciousness and the activities of Valentin Vodnik; the rebirth of Croatian national consciousness and the activities of Ljudevit Gaj; the rebirth of Serbian national consciousness and the activities of Vuk Karadžić; and the actions of Croats and Serbs during the revolutions of 1848. Furthermore, the curriculum covered the governments of Miloš and Mihailo Obrenović; the pro-Yugoslav activity of Josip Juraj Strossmayer; the 1875-1876 revolt in Bosnia-Herzegovina; the declaration of independence of the Principalities of Serbia and Montenegro; the Austro-Hungarian occupation of Bosnia-Herzegovina; the life of King Petar I Karađorđević; the actions of the chetniks in "Southern Serbia"; and the annexation of Bosnia-Herzegovina. Finally, also included were Serbia in the Balkan wars; Young Bosnia and the assassination of the Austrian crown prince in Sarajevo; First World War; the fall of Austria-Hungary; and the formation of Yugoslavia and the life of King Alexander I Karađorđević. ${ }^{34}$ The Illyrian Provinces were one of the few themes in the curriculum which did not strictly belong to Serbia's historical heritage. However, their history was considered a part of the cultural code shared by all of Yugoslav society. For that reason, the Illyrian Provinces were taught in the curricula of both primary and secondary schools as an important part of the history of Yugoslavia. ${ }^{35}$

grad: Službeni list SRJ, 2002), 35-37.

${ }^{31}$ Dimić, Kulturna politika Kraljevine Jugoslavije, Vol. I, 56.

32 Troch, "Education and Yugoslav Nationhood," 147.

33 Ibid., 148.

34 Ibid., 149.

35 Ibid., 236-237. 
The topic of the Illyrian Provinces was linked in an interesting way to the First Serbian Uprising in the curriculum. As mentioned above, the Uprising in 1804 and its leader Karađorde, the progenitor of the ruling dynasty, were presented as the cornerstone of the construction of Yugoslavia. They were identified as a stroke of genius on the part of Napoleon, who realized the Southern Slavs' true potential. They also inspired the Austrian Yugoslavs, who appreciated the efforts of the fighting Serbs and wished to dump the Habsburg shackles as the Serbs had shed the Ottoman yoke. Presented in that way, the administrative form of the Illyrian Provinces, which united a part of the Southern Slavs' home in Austria, was another source of inspiration for future pro-Yugoslav agitation. ${ }^{36}$

\section{The Illyrian Provinces as an Element that Strengthened the Pro-Yugoslav Narrative in Academic Research}

The depiction of the Illyrian Provinces as a step toward the creation of Yugoslavia was also a theme in the scientific works and articles of Yugoslav academicians. The academic community was another socio-professional group that very quickly accepted a centralized organization controlled by the Yugoslav government's Ministry of Science. On October 5-7, 1920, the annual meeting of the Serbian Professorship Society was held. Representatives of the Serbian academic community and professors from other regions of the Kingdom of SHS took part in the meeting. ${ }^{37} \mathrm{~A}$ decision was made there to create a United Society of Professors with branches in Belgrade, Ljubljana, Zagreb, Split, Sarajevo and Novi Sad. The main task of the new body was described as follows by Dušan Manđer in a fiery speech:

I came to Serbia, to Belgrade, which created Yugoslavia, and who will create the Yugoslavians, if not us, the professors? Apart from our brave Serbian army, there is one more army, which is the teachers and professors. We may differ in social, cultural and political views, but we must be unanimous and united - in the desire to make our country strong and united, and to make our nation strong and united too. ${ }^{38}$

In fact, for the Society, the most important task of the intelligentsia was to assist in the educational and cultural integration of Yugoslav society. ${ }^{39}$ Besides

\footnotetext{
${ }^{36}$ Ibid., 242.

37 Dimić, Kulturna politika Kraljevine Jugoslavije, Vol. II, 294.

38 Ibid., 294-295.

39 Ibid., 303.
} 
the well-prepared teaching programs in primary schools, university education also had to help create a Yugoslav national consciousness.

In Yugoslavia's interwar historiography there are many works written by scientists that support the Yugoslavian idea with scientific arguments. That is true of almost every field of science, to mention only the geographic and ethnographic works of the eminent Serbian geographer Jovan Cvijić, who during the First World War was trying to build a scientific foundation for a Yugoslav state, ${ }^{40}$ and the monumental work of the Croatian philosopher and ethnopsychologist Vladimir Dvorniković, entitled Karakterologija Jugoslovena. ${ }^{41}$ Many historians also supported Yugoslav national unification in their works. Among the most important were Ferdo Šišić and Viktor Novak. What is interesting is that they were both Croats who relied on the history of the Illyrian Provinces to legitimize and strengthen the Yugoslav idea.

A great example of such work is an article by Šišić published in an English brochure, The Yougoslavic Littoral on the Adriatic Sea, entitled "Historical Survey on the East Coast of the Adriatic Sea." ${ }^{42}$ In his text, Ššić commented on the continuity of Yugoslavian [sic] history on the Dalmatian Adriatic coast, from the early Middle Ages and the arrival of the Slavs on the Balkan Peninsula until the time of his contemporaries. He viewed the Illyrian Provinces as one of the important stages in the history of the Yugoslavian presence in the area. Although the period of French rule was relatively short, Šišić believed that "never before had the Yugoslav people had such a noble and kindly ruler as General Marmont." 43 Šišić identified the inhabitants of the Illyrian Provinces as Yugoslavs - not Slovenes, Croats or Serbs - who, for the first time in history, enjoyed the support of a ruler who treated them as one nation. The French introduced many reforms that accelerated the development of the Provinces. What is more, Šišić believed that the fall of Napoleon was one of the most disappointing blows the Yugoslav countries had ever received. ${ }^{44}$

\footnotetext{
40 E.g. Jovan Cvijić, Balkansko poluostrvo ijužnoslovenske zemlje: osnovi antropogeografije (Beograd: Zavod za izdavanje udžbenika, 1922). For Cvijić's activity during the First World War, see Trgovčević, Naučnici Srbije.

${ }^{41}$ Vladimir Dvorniković, Karakterologija Jugoslovena (Beograd: Kosmos, 1939).

${ }^{42}$ Ferdo Šišić, "Historical Survey on the East Coast of the Adriatic Sea," in The Yougoslavic Littoral on the Adriatic Sea, ed. Milan Rojc (Zagreb: Government Press, 1919), 15-26.

43 Šišić, "Historical Survey," 25. General Auguste Marmont was governor of the Illyrian Provinces from 1809 to early 1811. Regarding his rule in the Illyrian Provinces, see e.g. Prpić, "French Rule in Croatia," 245-254.

44 Šišić, "Historical Survey," 25.
} 
The article "Yugoslavic Civilization on the Adriatic," published in the same brochure, was written in the same vein. Its author was Branko Vodnik, a Croatian writer, critic and historian of literature. ${ }^{45} \mathrm{He}$ also claimed that the Illyrian Provinces were a very important stage on the road to implementing the Yugoslavian idea, because they were "the first state organism for centuries in which the various Yugoslavian tribes were united." 46 Together with the ideals of the French Revolution, the Provinces introduced the civilization of the Enlightenment and a modern understanding of nationhood to the Balkans, which had a significant impact on the creation of Yugoslav nation. To sum up, according to Branko Vodnik, despite the fact that they only existed for a few years the Illyrian Provinces lasted long enough to instill a Yugoslav idea in the Southern Slavs (Serbs, Croats and Slovenes). From that time on, all the rulers of those areas referred in some way to the Yugoslav idea, which only gathered strength until its final triumph. ${ }^{47}$

As can be seen in the work of both scholars, the Illyrian Provinces were considered to be the first stage of Yugoslav unification, confirming a common Yugoslavian identity for the Croats, Slovenians and Serbs. Their influence on the development of the Yugoslav idea was invaluable. Of course, one must pay attention to the context in which the English-language brochure mentioned above was published. In 1919, Italy was waging an intense diplomatic struggle with the Kingdom of SHS to gain access to the Adriatic coast of Dalmatia. The brochure, released in the widely-known English language, certainly had some propaganda goals. In the context of Woodrow Wilson's aim of self-determination for nations, a historical argument for the Yugoslav character of those lands was priceless. The brochure's emphasis was not on the Croatian, but the Yugoslav character of the local population. This was not without significance, because during the First World War the Croatians had fought alongside the armed forces of the defeated Habsburg monarchy, which they began to oppose only when its fall became inevitable. There is no doubt, however, that the narrative of the Illyrian Provinces as the first attempt at unification of all Yugoslav peoples under one state administration was a cornerstone of pro-Yugoslav ideology during the reign of King Alexander. It was repeated many times over.

The importance of the Illyrian Provinces was also reflected in a monumental work entitled Antologija jugoslovenske misli i narodnog jedinstva: 1390-1930,

\footnotetext{
${ }^{45}$ Branko Vodnik, "Yugoslavic Civilization on the Adriatic," in The Yougoslavic Littoral on the Adriatic Sea, ed. Milan Rojc (Zagreb: Government Press, 1919), 27-44.

${ }^{46}$ Ibid., 40.

${ }^{47}$ Ibid., 41.
} 
edited by Viktor Novak. ${ }^{48}$ Novak's anthology is a collection of works by South Slav creators of culture and speeches by political activists and others who over the centuries appealed to and emphasized the common Yugoslav heritage of the Southern Slavs. The first texts of the anthology are excerpts from books by Ferdo Sišićc ${ }^{49}$ and Vladimir Ćorović, ${ }^{50}$ which remember the Bosnian king Stefan Tvrtko, who crowned himself the ruler of all the Southern Slavs. ${ }^{51}$ The last text in the book is an excerpt from a speech by King Alexander Karađorđević delivered on January 12, 1930, as a response to a greeting from the Danube, Drava, and Drina Banovinas' parliamentary delegations. The speech ended with the following call:

Speak gentlemen, during travel and at home, tell one and all that no borders divide us anymore, nor [the mistakes] of the past, nor do the Danube, Sava or Drina separate [us], but they bind us forever and combine national soul and national interest into an inseparable whole - Yugoslavia, which no one will ever split. With this desire I greet you: Živeli! [Cheers!].52

The anthology also contains other texts depicting the Illyrian Provinces as one stage in the crystallization of the Yugoslav idea and its incarnation in the form of a united state of Southern Slavs. An excellent example of the continuity (that is, the inseparable connection between the Illyrian Provinces, the Yugoslav idea, and the Kingdom of SHS), was a fragment of an 1810 letter written by Karađorđe to Napoleon. ${ }^{53}$ The great leader of the First Serbian Uprising praised Napoleon as the man whom many nations, including Illyria - inhabited by "our tribesmen" - should thank for the resurrection of their countries. ${ }^{54}$ The phrase "our tribesmen" used by the founder of the Karađorđević dynasty to refer to the inhabitants of the Illyrian Provinces confirms that the Serbs then considered all

${ }^{48}$ Viktor Novak, Antologija jugoslovenske misli i narodnog jedinstva (1390-1930) (Beograd: [n.p.], 1930).

${ }^{49}$ Ferdo Šišić, Pregled povijesti hrvatskog naroda: od najstarijih dana do 1 decembra 1918 (Zagreb: S. Kugli, knjižara kr. Sveučilišta i Jogoslav. akademije, 1920), 185-191.

50 Vladimir Ćorović, Kralj Tvrtko I Kotromanić (Beograd: Makarije, 1925).

${ }^{51}$ Novak, Antologija jugoslovenske misli, 1-2.

52 "Recite, Gospodo, uz put i na domu, - recite svima i svakome, da nas nikakve granice, ni podvojenosti iz prošlosti, kao ni Dunav ni Sava, ni Drina više ne razdvajaju, već da nam uvek vezuju i spajaju interese narodne i dušu narodnu u nerazdvojnu celinu - Jugoslaviju, koju nikad niko razjediniti neće. Sa ovakom željom, Ja Vas pozdravljam: Živeli!" Quoted in Novak, Antologija jugoslovenske misli, 896-897.

53 This letter appeared originally in Karađorđe. Život i delo, ed. Vladimir Ćorović, Stanoje Stanojević and Ferdo Sišić (Beograd: Narodno delo, 1923), 63.

${ }^{54}$ Novak, Antologija jugoslovenske misli, 32. 
the inhabitants of the Provinces (in which, let us recall, the Serbs were in the minority) to be their co-tribesmen. This belief of the time supported the narrative of the Illyrian Provinces as the first successful attempt to unite the Yugoslavs. The fact that Karađorđe was the great-grandfather of King Alexander legitimized Alexander's pro-Yugoslav policies, making his actions more authentically patriotic and consistent with an idea that had originated many years earlier.

Other texts in the Novak anthology that refer to the heritage of the Illyrian Provinces were the poems Ilirija oživljena (Illyria Reborn) and Ilirija zveličana (Illyria Saved) by Valentin Vodnik, one of the first modern Slovenian poets. In his poems, Vodnik praises Napoleon for "resurrecting" Illyria. ${ }^{55}$ Novak's inclusion of these poems in his anthology was intended to emphasize the joy that the Slovenian elites felt in the creation of the Provinces, and thus the unification of all the Yugoslav nationalities under one administration. Even though it probably was not Vodnik's intention, Novak introduced his poems into the canon of Yugoslav literature and thought. Vodnik thus contributed to strengthening the narrative of the Illyrian Provinces as a waypoint on the path to the creation of Yugoslavia, a goal which met with the general approval of the Slovenian elites.

\section{Conclusion}

There is no doubt that the memory of the Illyrian Provinces was widely used by the government in the interwar Yugoslavia to bolster its legitimacy. The Provinces were identified as one of the most important stages on the way to the creation of a unified Yugoslavia. The main mediator of this idea was the core curriculum of the schools, which exposed all Yugoslav students to the collective-identity-building events in the tradition of each part of Yugoslavia's society. The pedagogical presentation of the Illyrian Provinces as one of the first attempts to create Yugoslavia was aimed at convincing the Slovenian and, to a lesser extent, also Croatian inhabitants of the Kingdom of the value of the Yugoslav idea, which up to then had been built mainly on the Serbian historical-cultural narrative. Through the school curriculum, the authorities intended to show that the heritage of the Illyrian Provinces was the common heritage of all Yugoslavs. The goal was a society of men and women who identified themselves as Yugoslavs, of the species homo yugoslavicus.

The narrative was further strengthened by pro-Yugoslav representatives of science, who tried to show in their academic works the continuity and

55 Ibid., 33-43. 
connection of the Illyrian Provinces and their inhabitants with the contemporary Yugoslavia. Yet, this way of thinking largely failed to change the popular mindset in Yugoslavia as a whole. The memory of the Illyrian Provinces was most vivid in the Drava Banovina, which actually lived through the experience. Despite numerous efforts of the Yugoslav authorities, the attempt to turn the Illyrian Provinces into a common denominator for the whole of Yugoslav society was rather unsuccessful. The division of the country into new banovinas carried out in October 1929 did not help either. ${ }^{56}$ The predominance of the Serbian element in the pro-Yugoslav narrative proved to be too obvious, and ultimately thwarted the attempt to create a unified Yugoslav society.

56 Troch, "Education and Yugoslav Nationhood," 270-276. 